\title{
Response Surface Methodology in Spectrophotometric Estimation of Saxagliptin, Derivatization with MBTH and Ninhydrin
}

\section{Saksagliptinin Spektrofotometrik Tahmininde Tepki Yüzey Metodolojisi, $M B T H$ ve Ninhidrin ile Türevlendirme}

\author{
(D) Sunitha GURRALA 1 , (D) Shiva RAJ2*, (D) Subrahmanyam CVS 3 , (D) Durga Panikumar ANUMOLU³, (D) Swathi NARAPARAJU33, \\ (D) Harika NIZAMPET ${ }^{3}$ \\ 1Osmania University, University College of Technology, Department of Pharmacy, Hyderabad, India \\ 2Osmania University, University College of Science, Department of Chemistry, Hyderabad, India \\ ${ }^{3}$ Osmania University, Gokaraju Rangaraju College of Pharmacy, Hyderabad, India
}

\begin{abstract}
Objectives: Design of experiments assisted spectrophotometric methods have been established for the quantification of saxagliptin in pharmaceutical formulation via charge transfer complexation and Schiff's base formation.

Materials and Methods: Box-Behnken design was exploited in method-1, involved the measurement of absorbance of green/blue-colored complex (at $600 \mathrm{~nm}$ ), formed by the reaction of saxagliptin with 3-methyl-2-benzothiazolinone hydrazone in the presence of ferric chloride. The central composite design was employed in method-2, involved the determination of absorbance of Ruhemann's purple (at $585 \mathrm{~nm}$ ), formed by the reaction of the primary amine group of saxagliptin with ninhydrin reagent in presence of sodium hydroxide. Optimization of reaction variables namely, reagent concentration (A), oxidizing agent/alkalinity $(B)$ and reaction/heat time $(C)$ was performed through response surface methodology for the response $(Y)$ i.e. absorbance of colored compound. The reliability of both methods was investigated through validation as per International Council for Harmonisation guidelines.

Results: Saxagliptin executed linearity in the concentration range of $0.01-0.25 \mu \mathrm{g} / \mathrm{mL}$ and $1-10 \mu \mathrm{g} / \mathrm{mL}$ by method-1 and 2 . A high value of molar absorptivity, low values of Sandell's sensitivity and limit of detection/limit of quantification divulges the good sensitivity methods. The \% assay of saxagliptin in the marketed formulation was found to be 100.27 and 99.86 by method-1 and method-2, respectively.

Conclusion: The proposed eco-friendly and economical methods can be routinely employed in quality control for the analysis of saxagliptin in the pharmaceutical dosage forms.
\end{abstract}

Key words: Saxagliptin, MBTH, ninhydrin, BBD, CCD

öz

Amaç: Farmasötik formülasyonlarda saksagliptin miktarının yük transfer kompleksasyonu ve Schiff bazı oluşumu yolları ile belirlenmesi için spektrofotometrik yöntem destekli deney tasarımı oluşturulmuştur.

Gereç ve Yöntemler: Yöntem-1'de, demir klorür varlığında, saksagliptin ile 3-metil-2-benzotiazolinon hidrazonun reaksiyonuyla oluşturulan yeșil/mavi renkli kompleksin (600 nm'de) absorbansının ölçülmesini kapsayan Box-Behnken tasarımı kullanılmıştır. Yöntem-2'de, sodyum hidroksit varlığında, saksagliptinin primer amin grubunun ninhidrin reaktifi ile reaksiyonuyla oluşturulan Ruhemann morunun ( 585 nm'de) absorbansının belirlenmesini kapsayan merkezi kompozit tasarımı kullanılmıștır. Reaktif konsantrasyonu (A), oksitleyici ajan/alkalinite (B) ve reaksiyon/ısı süresi (C) belirlenen reaksiyon değişkenleridir ve optimizasyon, renkli bileşiğin absorbansı gibi cevaplar (Y) için, tepki yüzeyi metodolojisi yoluyla gerçekleştirilmiştir. Her iki yöntemin güvenilirliği, Uluslararası Harmonizasyon Konseyi yönergelerine göre validasyon yoluyla gerçekleştirilmiştir.

Bulgular: Saksagliptinin doğrusalık aralığı metot-1 ve 2 için sırasıyla 0,01-0,25 $\mu \mathrm{g} / \mathrm{mL}$ ve 1-10 $\mu \mathrm{g} / \mathrm{mL}$ konsantrasyon aralığında uygulanmıştır. Yüksek değerli molar absorptivite, düșük değerli Sandell duyarlılığı ve tayin limiti/teşhis limiti değerleri yöntemlerin duyarlıığını ortaya koymaktadır. Pazarlanan formülasyondaki saksagliptin \% miktarı, yöntem-1 ve yöntem-2'ye göre sırasıyla 100,27 ve 99,86 olarak bulunmuştur. 
Sonuç: Ortaya konulan/önerilen çevre dostu ve ekonomik yöntemler, saksagliptinin farmasötik dozaj formlarındaki analizlerinde rutin olarak uygulanabilir.

Anahtar kelimeler: Saksagliptin, MBTH, ninhidrin, BBD, CCD

\section{INTRODUCTION}

Saxagliptin (Onglyza) is an oral antihyperglycemic drug belonging to the dipeptidyl peptidase-4 inhibitor class. ${ }^{1}$ Saxagliptin is indicated for patients with type 2 diabetes to improve glycemic control, used alone or along with metformin and/or insulin when these drugs do not provide adequate glycemic control. The recommended dose of saxagliptin is $2.5 \mathrm{mg} / 5 \mathrm{mg}$ once daily. ${ }^{2,3}$ Few methods were reported in the literature on the analysis of saxagliptin using ultraviolet (UV)spectrophotometric, ${ }^{4-11}$ spectrofluorometric, high-performance thin-layer chromatography ${ }^{12}$ and high-performance liquid chromatography ${ }^{13,14}$ techniques. Colorimetric methods are relatively simple, faster (in terms of sample preparation), inexpensive than chromatographic techniques, and more sensitive, specific over UV-spectrophotometry due to selective chemical reaction of analyte with the reagent to yield a colored derivative. ${ }^{15-19}$ The literature review revealed, two colorimetric reports ${ }^{20,21}$ for estimation of saxagliptin using chromogenic reagents [(2,3-dichloro-5,6-dicyano-1,4-benzoquinone); (7,7,8,8-tetracyanoquinodimethane); (1,2-naphthoquinone-4sulfonic acid); (4-chloro-7-nitrobenzofurazan)]. There was no method developed using proposed chromogenic agents such as 3-methyl-2-benzothiazolinone hydrazone (MBTH), ninhydrin, which can produce more sensitive and specific methods for the analysis of saxagliptin.

The literature methods used conventional strategy in experimentation i.e., varying one factor at a time, which may deliver ambiguous and inept optimization in analytical method development, so it must be avoided. This conventional strategy necessitating the use of systematic and statistical approach for optimization of method variables to attain consistent results, ${ }^{22,23}$ which can be achieved through analytical quality by design $(A Q b D)$ strategy. The $A Q b D$ in method development facilitates the simultaneous evaluation of significant variables though design of experiments and response surface analysis for accomplishing enhanced method performance..$^{24,25}$

The contemplated research exploited $A Q b D$ approach in the development of visible-spectrophotometric method for the estimation of the saxagliptin through chemical derivatization technique.

\section{MATERIALS AND METHODS}

\section{Instrumentation and chemicals}

The double beam 1800 UV-visible spectrophotometer (Shimadzu, Japan), analytical balance (Shimadzu AUX 220, Japan) and ultrasonic cleaner (Sonica) were used for the study. Ethanol was purchased from Qualigens, Mumbai. Ferric chloride, sodium hydroxide, MBTH and ninhydrin were purchased from SD Fine-Chem Ltd., Mumbai. Double distilled water was used throughout the study. Saxagliptin standard gift sample was provided by Hetero Laboratories Pvt Ltd., Hyderabad, India. Marketed dosage form (Onglyza ${ }^{\circledR}$, AstraZeneca) of saxagliptin was procured from the local pharmacy.

Experimental design, data analysis and response surface plots were developed employing Design-Expert trial version 11.0.5.0 software (Stat-Ease Inc. Minneapolis).

\section{Preparation of solutions}

The standard stock solution $(100 \mu \mathrm{g} / \mathrm{mL})$ of saxagliptin was prepared by solubilizing accurately weighed $10-\mathrm{mg}$ saxagliptin in $10-\mathrm{mL}$ ethanol and diluted to $100 \mathrm{~mL}$ with distilled water. Working standard solution-1 was prepared by diluting $1 \mathrm{~mL}$ standard stock solution to $10 \mathrm{~mL}$ with distilled water to get $10 \mu \mathrm{g} / \mathrm{mL}$ of saxagliptin. Working standard solution-2 was prepared by diluting $0.1 \mathrm{~mL}$ working standard solution-1 to 10 $\mathrm{mL}$ with distilled water to get $0.1 \mu \mathrm{g} / \mathrm{mL}$ of saxagliptin.

Solutions of $\mathrm{MBTH}$ reagent $(1.1 \% \mathrm{w} / \mathrm{v})$, ferric chloride $(3.5 \%$ $\mathrm{w} / \mathrm{v})$, ninhydrin $(1 \% \mathrm{w} / \mathrm{v})$ and sodium hydroxide $(0.4 \mathrm{M})$ were prepared in distilled water.

\section{Experimental design and optimization}

Method-1: Box-Behnken design (BBD) with response surface methodology (RSM) was employed to optimize reaction (saxagliptin-MBTH) conditions for colorimetric method development. The effect of three method variables (at high, low levels), such as the concentration of MBTH (A1): $0.8,1.2 \%$ $\mathrm{w} / \mathrm{v}$; concentration of ferric chloride (B1): $1,5 \% \mathrm{w} / \mathrm{v}$; reaction time (C1): 10-30 min; on the response (Y1) i.e., absorbance of bluish-green coloured complex was studied at $600 \mathrm{~nm}$ in spectrophotometer. Randomized order in experimentation was followed to abate the bias effects of uncontrolled variables for 17 experimental runs under BBD using working standard solution-2 $(0.1 \mu \mathrm{g} / \mathrm{mL})$.

Method-2: Central composite design (CCD) with RSM was exploited to optimize experimental conditions for colorimetric estimation of saxagliptin, upon derivatization with ninhydrin reagent. Working standard solution-1 $(10 \mu \mathrm{g} / \mathrm{mL})$ was used for experimentation. This method optimization was premeditated with 15 experimental runs under CCD (4 factorial points, 5 center points and 6 axial points) to study the influence and interaction of three method parameters (at high, low levels) namely, concentration of ninhydrin reagent (A2): $0.8,1.2 \% \mathrm{w} / \mathrm{v}$; concentration of sodium hydroxide (B2): $0.2,0.6 \mathrm{M}$; heating time (C2): 5, $15 \mathrm{~min}$; on the response (Y2) i.e. absorbance of Ruhemann's purple, measured at $585 \mathrm{~nm}$ in a spectrophotometer.

\section{Statistical analysis}

Statistical analysis was performed together with the experimental design (BBD/CCD) in Design-Expert software. 
The significance of variables was studied through ( $p$ values) ANOVA. Multiple regression analysis was performed and estimated the correlation coefficient $\left(r^{2}\right)$ for response studied. The main and interaction effects of variables were detected via best-fitted models, selected based on various parameters like predicted error sum of squares (PRESS), R² (adjusted, predicted), \% coefficient of variation ( $\mathrm{CV}$ ), adequate precision and lack of fit analysis. Contour plots (2D) and response surface plots (3D) were employed for quantitative identification of influence of each variable (along with interaction) on the response $(Y)$. The design space was generated as a multidimensional combination between variables and response for the maximum desirability function.

\section{Validation of methods}

The proposed methods were validated ${ }^{26}$ for linearity, accuracy, precision, limit of detection (LOD), and limit of quantification (LOQ) as per the International Conference on Harmonization (ICH) guidelines.

\section{Linearity}

Method-1: Aliquots (0.01, 0.05, 0.1, 0.15,0.2, $0.25 \mathrm{~mL}$ ) of standard solution $(10 \mu \mathrm{g} / \mathrm{mL})$ of saxagliptin were taken into a series of 10 $\mathrm{mL}$ volumetric flasks. To these $0.5 \mathrm{~mL}$ of $1.1 \% \mathrm{MBTH}$ solution and $0.5 \mathrm{~mL}$ of $3.5 \% \mathrm{FeCl}_{3}$ were added, shaken vigorously and kept a side for $20 \mathrm{~min}$. Then volume was then made up to the mark with water to prepare a series of standard solutions containing $0.01-0.25 \mu \mathrm{g} / \mathrm{mL}$ of saxagliptin. Then, the absorbance of the blue-green colored chromogen was measured at $600 \mathrm{~nm}$ against corresponding reagent blank. The amount of saxagliptin was computed from the Beer-Lambert's plot.

Method-2: Aliquots $(0.1,0.2,0.4,0.6,0.8,1 \mathrm{~mL})$ of standard drug solution $(100 \mu \mathrm{g} / \mathrm{mL})$ of saxagliptin were taken into a series of $10 \mathrm{~mL}$ volumetric flasks. To these $2 \mathrm{~mL}$ of $1 \%$ ninhydrin reagent, $2 \mathrm{~mL}$ of $0.4 \mathrm{M} \mathrm{NaOH}$ was added, shaken vigorously and heated for $13 \mathrm{~min}$. The volume was then made up to the mark with water to prepare a series of standard solutions containing $1-10 \mu \mathrm{g} / \mathrm{mL}$ of saxagliptin. Then, the absorbance of the yellowpurple colored chromogen was measured at $585 \mathrm{~nm}$ against corresponding reagent blank. The amount of saxagliptin was computed from the Beer-Lambert's plot.

\section{Precision}

The intra-day and inter-day precision of the proposed colorimetric methods were determined for three different concentrations of saxagliptin within the linearity range. Estimated the corresponding response of solutions prepared three times on the same day and three different days of a week. The results were reported in terms of relative standard deviation (\% RSD).

\section{Accuracy}

The accuracy of the method was determined by calculating recoveries of saxagliptin using the method of standard additions. Known concentration of saxagliptin solutions were added at 80,100 , and $120 \%$ levels to pre-quantified sample solutions of saxagliptin and analyzed through proposed methods. Each sample was prepared in triplicate at each level. The amount of saxagliptin was estimated by applying the obtained values to regression equation.

\section{Sensitivity}

The LOD and LOQ of saxagliptin by proposed methods were derived from the standard calibration curve using $3.3 \mathrm{\sigma} / \mathrm{s}$ and $10 \mathrm{\sigma} / \mathrm{s}$, formulae, respectively, where $\mathrm{s}$ is the slope of the calibration curve and $\sigma$ is standard deviation of the $y$-intercept of regression equation. ${ }^{27}$

\section{Assay of saxagliptin marketed dosage form}

Twenty tablets of saxagliptin (Onglyza ${ }^{\circledR}$ ) were weighed and powdered. The powder quantity equivalent to $10 \mathrm{mg}$ of the drug was dissolved in $10 \mathrm{~mL}$ ethanol, filtered (using Whatman's filter paper) into $100 \mathrm{~mL}$ volumetric flask and made the volume up to the mark with distilled water. From this $1 \mathrm{~mL}$ was transferred into a $10 \mathrm{~mL}$ volumetric flask, added $2 \mathrm{~mL}$ of $1 \%$ ninhydrin reagent and $2 \mathrm{~mL}$ of $0.4 \mathrm{M}$ sodium hydroxide, shaken vigorously and heated for $13 \mathrm{~min}$ (method-2). For method-1, further filtrate (1 $\mathrm{mL}$ diluted to $10 \mathrm{~mL}$ with water) was diluted. To this $0.1-\mathrm{mL}$ solution, added $0.5 \mathrm{~mL}$ each $1.1 \% \mathrm{MBTH}$ and $3.5 \% \mathrm{FeCl}_{3}$, shaken vigorously and kept aside for $20 \mathrm{~min}$. The volume was made up to the mark with distilled water. The absorbance of the resulting colored solution was measured at 600 (method-1)/585 $\mathrm{nm}$ (method-2) against the corresponding reagent blank. The amount of saxagliptin was calculated from the Beer-Lambert's plot.

\section{RESULTS AND DISCUSSION}

\section{Basis for color development}

Direct spectroscopy method for analysis of a saxagliptin in pharmaceutical formulation may prone interferences due to matrix effect. Chemical derivatization of drug enhances selectivity and sensitivity of the method. The proposed methods subjugated the saxagliptin to chemical derivatization using chromogenic reagents (MBTH and ninhydrin) for its visible spectroscopic analysis.

In method-1, saxagliptin undergoes an oxidative coupling reaction with MBTH in the presence of oxidizing agent (ferric chloride) to produce bluish-green colored chromogen. Initially, oxidation (loss of 2 electrons and 1 proton) of MBTH by ferric chloride occurs to give an electrophilic intermediate, which coupled at the most nucleophilic site of saxagliptin and forms a bluishgreen colored chromogen (Figure 1), which absorbs visible light maximally at a wavelength of $600 \mathrm{~nm}$ in a spectrophotometer.

In method-2, ninhydrin undergoes tautomerism (with loss of water) to 1,2,3-indane trione, which actively reacts with the primary amine group of saxagliptin and forms a Schiff base. In this reaction attack of the nucleophile (amine) on the electrophile (carbonyl group) of 1,2,3-indane, followed by dehydration occurs. Further hydrolysis gives an intermediate amine due to isolation of carbonyl compound. A deep blue/purple color compound (diketohydrindylidene-diketohydrindamine) extensively known as Ruhemann's purple produces upon 
condensation of an intermediate amine with another molecule of ninhydrin (Figure 2), exhibiting absorption maxima at $585 \mathrm{~nm}$ in a spectrophotometer.

\section{Evidence of chemical derivatization}

Saxagliptin chemical derivatization with proposed reagents was evidenced by the thin layer chromatography (TLC) analysis of reaction mixture. Pre-coated TLC plates were spotted separately for method- 1 and 2 with a freshly prepared solution of saxagliptin, reagent blank solution and chromogen produced using that method. Plates were developed in saturated chromatographic tanks using ethyl acetate: acetonitrile (7:3) as a mobile phase and spots were visualized in the UV chamber at $254 \mathrm{~nm}$. Three spots were observed with different retention factor values on both plates (method-1 and method-2), indicates three different compounds. Higher retardation factor values were observed for derivatives (Supplementary 1), denotes the formation of a new compound by the proposed reaction mechanism.

\section{Method optimization via $A Q b D$ approach}

Optimization of reagent concentration, diluting solvent and time for color development was established to accomplish

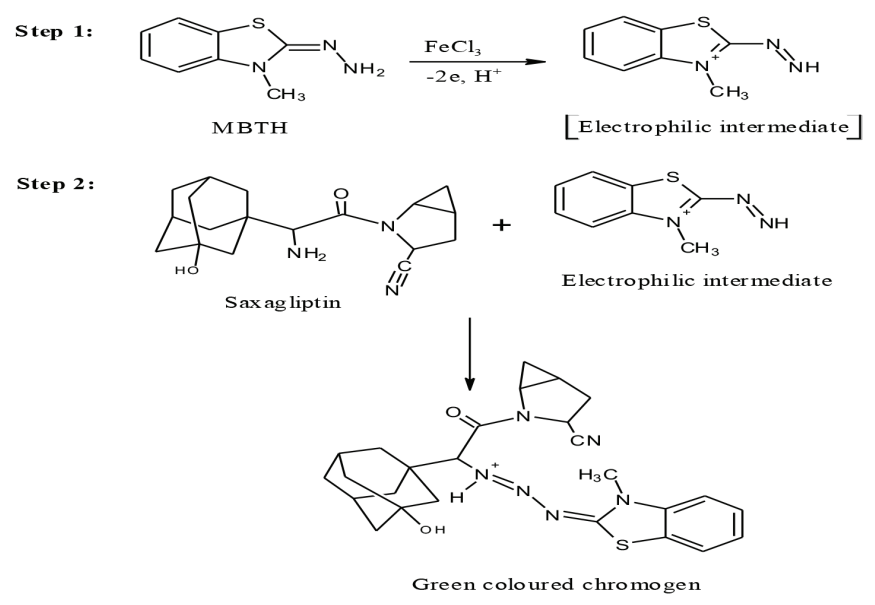

Figure 1. Oxidative coupling reaction between saxagliptin and MBTH MBTH: 3-methyl-2-benzothiazolinone hydrazone

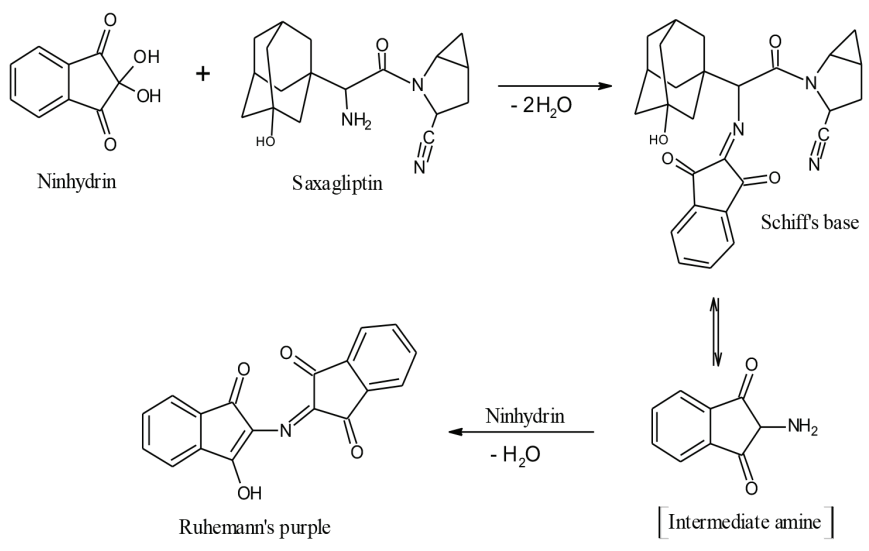

Figure 2. Schiff's base formation and condensation of saxagliptin with ninhydrin maximum absorbance and stability. The influence of variables on absorption values of colored species was studied by multivariate approach.

The matrix of BBD, CCD and results of experimental runs performed on UV-visible spectrophotometer are provided in Table 1. ANOVA was performed for experimental observations to evaluate the significant effect of variables on the response, summarized in Table 2. The experimental results are fitted to a second-order polynomial (quadratic) model for the response $Y$ being studied (absorbance), given by the following equations:

$Y 1=0.5830+0.0426 A_{1}+0.0413 B_{1}+0.0106 C_{1}+0.0032 A_{1} B_{1}+0.0040$ $\mathrm{A}_{1} \mathrm{C}_{1}+0.0062 \mathrm{~B}_{1} \mathrm{C}_{1}-0.0390 \mathrm{~A}_{1}{ }^{2}-0.0593 \mathrm{~B}_{1}{ }^{2}-0.0190 \mathrm{C}_{1}{ }^{2}$ $\mathrm{Y} 2=+0.9808+0.0788 A_{2}+0.0198 B_{2}+0.0431 C_{2}-0.0444 A_{2} B_{2}$ $+0.0438 A_{2} C_{2}+0.0433 B_{2} C_{2}-0.0726 A_{2}{ }^{2}-0.0824 B_{2}{ }^{2}-0.0379 C_{2}{ }^{2}$

Statistical analysis data of both methods reveal the significant effect of three variables $(A, B, C)$ on the response under study as their $p$ values (probability) found below the considered value ( $p<0.05$ ) at $95 \%$ confidence levels. The high values of regression co-efficient $\left(r^{2}>0.999\right)$ obtained, indicates the good correlation between the experimental data and the selected models. $\mathrm{CV}$ found to be less than $5 \%$, indicates the reproducibility of model. The values of low PRESS, high adequate precision (>4), agreement between the predicted and adjusted $R^{2}$ (difference <0.2) denoted the model aptness.

The sensitiveness of a specific response by the perturbation of an individual factor from its reference value (while other factors kept constant) was studied through the construction of perturbation plots. The steepest slope of perturbation plots (Supplementary 2a) observed, indicates that the response (absorbance) in method-1 is highly influenced by the concentration of MBTH (A1) followed by the concentration of ferric chloride (B1). Curvature in plots (Supplementary 2b) indicate the response (absorbance) in method-2 is highly affected by the concentration of ninhydrin (A2) and followed by reaction heating time (C2). Variable-response relationship was visualized through contour (2D) and response surface (3D) graphs. These plots can be used to find the response for a given set of input variables, the non-linear trend in response surfaces (Supplementary 3,4) was observed, reveals the existence of a high degree of interaction (among variables) that effects the method response. Optimization of variables for maximum spectrophotometric absorbance at respective wavelengths was carried out using Derringer's desirability function. The solution with maximum desirability value is selected as an optimized one, out of different solutions provided by the software. The design space generated is portrayed in Figure 3, indicated high performance owing to maximum desirability value (equal to 1) for both methods and unveiled method operable design region with the location of the optimized solution for the design studied.

The optimized conditions interpreted from statistical and response surface analysis are as follows. Method-1: $1.1 \%$ $\mathrm{w} / \mathrm{v}$ MBTH (A1), 3.5\% w/v ferric chloride (B1) and reaction time $20 \mathrm{~min}(\mathrm{C} 1)$. Method-2: 1\% w/v ninhydrin reagent (A2), $0.4 \mathrm{M}$ sodium hydroxide (B2) and reaction heating time $13 \mathrm{~min}$ (C2). These reaction conditions are adequate for 
Table 1. Box-Behnken design, central composite design and experimental results

\begin{tabular}{|c|c|c|c|c|c|c|c|c|c|}
\hline \multicolumn{5}{|c|}{ Box-Behnken design } & \multicolumn{5}{|c|}{ Central composite design } \\
\hline \multirow{2}{*}{ Run } & \multicolumn{3}{|c|}{ Factors } & \multirow[t]{2}{*}{ Response } & \multirow{2}{*}{ Run } & \multicolumn{3}{|c|}{ Factors } & \multirow{2}{*}{$\begin{array}{l}\text { Response } \\
\text { Y2 }\end{array}$} \\
\hline & $\mathrm{A} 1$ & B1 & $\mathrm{C} 1$ & & & $\mathrm{~A} 2$ & B2 & $\mathrm{C} 2$ & \\
\hline 1 & 1 & 3 & 20 & 0.584 & 1 & 1.2 & 0.2 & 15 & 0.934 \\
\hline 2 & 0.8 & 5 & 20 & 0.477 & 2 & 1.2 & 0.6 & 5 & 0.711 \\
\hline 3 & 1 & 3 & 20 & 0.586 & 3 & 1 & 0.4 & 10 & 0.979 \\
\hline 4 & 1 & 5 & 10 & 0.529 & 4 & 1.28 & 0.4 & 10 & 0.948 \\
\hline 5 & 1.2 & 3 & 10 & 0.554 & 5 & 0.72 & 0.4 & 10 & 0.725 \\
\hline 6 & 0.8 & 3 & 10 & 0.479 & 6 & 0.8 & 0.2 & 5 & 0.688 \\
\hline 7 & 1 & 3 & 20 & 0.582 & 7 & 1 & 0.4 & 17 & 0.967 \\
\hline 8 & 0.8 & 3 & 30 & 0.488 & 8 & 1 & 0.4 & 10 & 0.977 \\
\hline 9 & 1.2 & 1 & 20 & 0.486 & 9 & 0.8 & 0.6 & 15 & 0.815 \\
\hline 10 & 1 & 1 & 30 & 0.468 & 10 & 1 & 0.4 & 10 & 0.981 \\
\hline 11 & 1.2 & 5 & 20 & 0.571 & 11 & 1 & 0.4 & 03 & 0.845 \\
\hline 12 & 1.2 & 3 & 30 & 0.579 & 12 & 1 & 0.68 & 10 & 0.845 \\
\hline 13 & 1 & 3 & 20 & 0.582 & 13 & 1 & 0.4 & 10 & 0.983 \\
\hline 14 & 0.8 & 1 & 20 & 0.405 & 14 & 1 & 0.18 & 10 & 0.789 \\
\hline 15 & 1 & 1 & 10 & 0.455 & 15 & 1 & 0.4 & 10 & 0.982 \\
\hline 16 & 1 & 5 & 30 & 0.567 & & & & & \\
\hline 17 & 1 & 3 & 20 & 0.581 & & & & & \\
\hline
\end{tabular}

A1: MBTH (\%), B1: Ferric chloride (\%), C1: Reaction time (min), Y1: Absorbance of blue-green complex, A2: Ninhydrin (\%), B2: $\mathrm{NaOH}(\mathrm{M}), \mathrm{C} 2: \mathrm{Heat}$ time (min), Y2: Absorbance of Ruhemann's purple, MBTH: 3-methyl-2-benzothiazolinone hydrazone

\section{Table 2. ANOVA and regression analysis of selected models}

\begin{tabular}{|c|c|c|c|c|c|}
\hline Response & $\mathrm{Y} 1$ & Y2 & & $\mathrm{Y} 1$ & Y2 \\
\hline Fit model & Quadratic & Quadratic & SD & 0.0037 & 0.0026 \\
\hline $\begin{array}{l}\text { Sum of } \\
\text { squares }\end{array}$ & 0.0541 & 0.1698 & Mean & 0.5278 & 0.8779 \\
\hline df & 9 & 9 & $\% \mathrm{CV}$ & 0.6952 & 0.2919 \\
\hline $\begin{array}{l}\text { Mean } \\
\text { square }\end{array}$ & 0.0060 & 0.0189 & $\mathrm{R}^{2}$ & 0.9983 & 0.9998 \\
\hline F value & 446.60 & 2873.81 & Adjusted $\mathrm{R}^{2}$ & 0.9960 & 0.9995 \\
\hline$p$ value & $<0.0001$ & $<0.0001$ & Predicted $\mathrm{R}^{2}$ & 0.9764 & 0.9937 \\
\hline \multirow{2}{*}{$\begin{array}{l}\text { Lack of fit } \\
\text { ( } p \text { value) }\end{array}$} & \multirow[t]{2}{*}{0.0509} & \multirow[t]{2}{*}{0.2670} & $\begin{array}{l}\text { Adequate } \\
\text { precision }\end{array}$ & 63.56 & 139.48 \\
\hline & & & PRESS & 0.0013 & 0.0011 \\
\hline
\end{tabular}

SD: Standard deviation, CV: Coefficient of variation, PRESS: Predicted error sum of squares

reproducible, maximum color development for spectroscopic estimation of saxagliptin and were verified through practical experimentation. The UV-visible absorbance spectrum of saxagliptin under optimized conditions was recorded (Supplementary 5) for method-1 and 2.

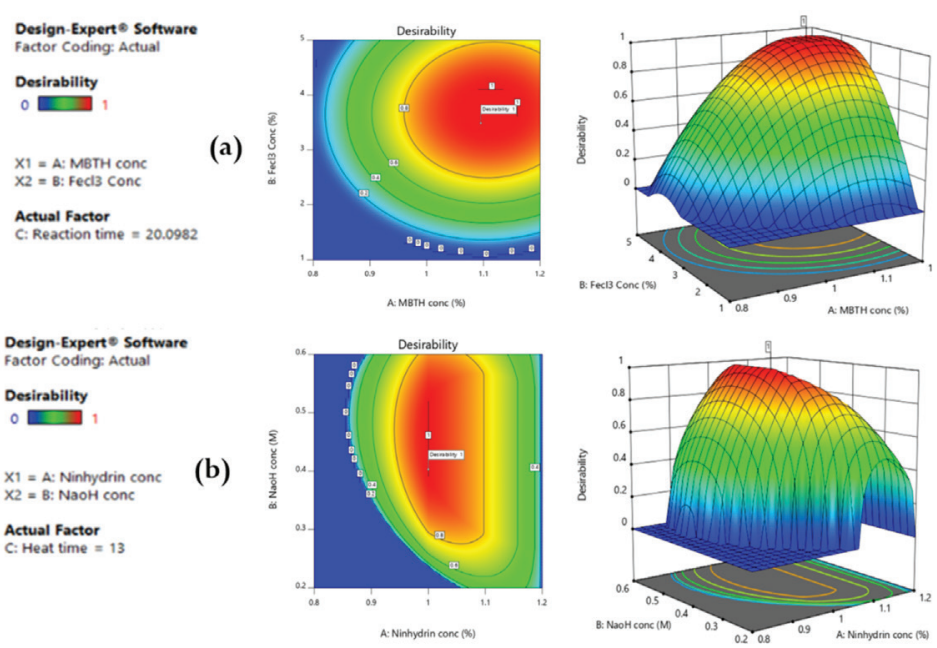

Figure 3. Desirability study (2D, 3D plot), (a): Design space for method-1, (b): Design space for method-2

\section{Effect of solvents}

Diluting solvent plays an important role in the stability of the colored complex. The effects of different diluting solvents, such as acetone, acetonitrile, ethanol, methanol, and distilled water have been studied (Figure 4) for measurement under optimized reaction conditions. The best sensitivity, maximum 
UV absorption, and product stability were attained when water was used as a solvent for both the methods. Both reagents were freely soluble in water. Hence, distilled water was selected as a diluting solvent for proposed methods that dwindle the cost of experiment and considered as a green approach for spectrophotometric method development.

\section{The stoichiometry of the reaction}

The stoichiometry of the reaction in method- 1 and method- 2 was studied by Job's continuous variation method. Equimolar solutions $\left(3.174 \times 10^{-6} \mathrm{M}\right)$ of saxagliptin and reagents (MBTH and ninhydrin) were prepared in distilled water. The drug and reagent (MBTH: method-1/ninhydrin: method-2) were mixed in various proportions to produce different mole ratio values $(0,0.2,0.4,0.5,0.6,0.8,1)$. These solutions were analyzed through the proposed methods. The stoichiometric relationship displayed in Figure 5. A mole ratio of 0.5 gave the highest absorbance value for method-1 whereas 0.7 for method- 2 . This mole ratio values indicates that saxagliptin has one center (primary amino group) available for the chromogenic reaction with MBTH (1 molecule) and ninhydrin (2 molecules) reagents at their optimum wavelengths.

\section{Validation of the proposed methods}

The proposed methods were statistically validated as per $\mathrm{ICH}$ guidelines and results are provided in Table 3. Linear

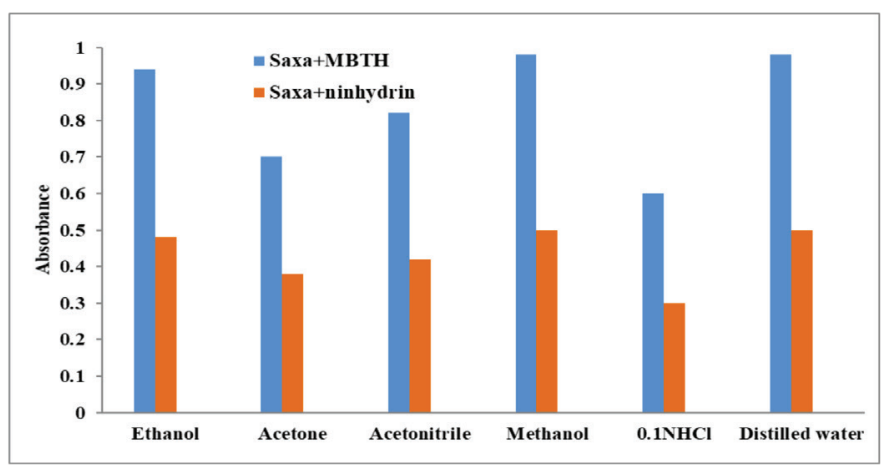

Figure 4. Effect of solvent on saxagliptin reaction with MBTH and ninhydrin MBTH: 3-methyl-2-benzothiazolinone hydrazone

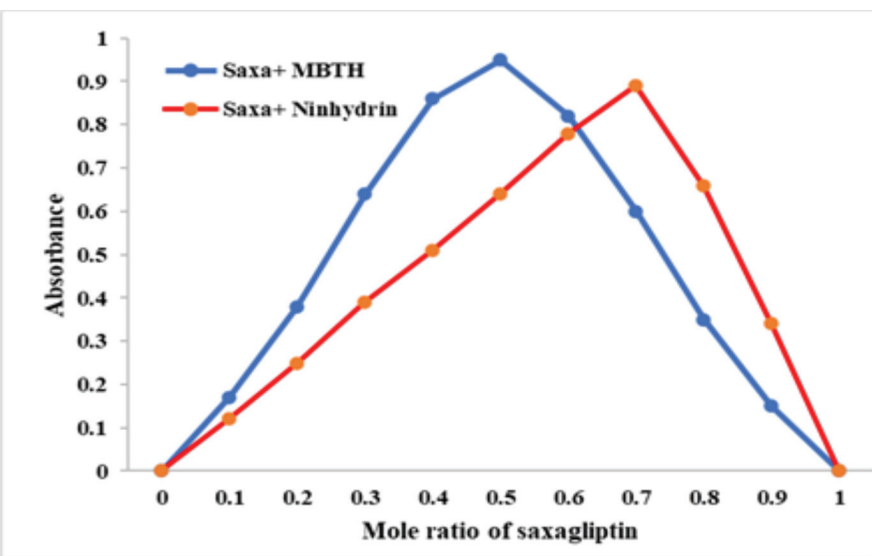

Figure 5. Job's continuous variation plot for method-1 and method-2 MBTH: 3-methyl-2-benzothiazolinone hydrazone regression analysis was performed for the Beer's Law data (Supplementary 6), and calibration plots (Supplementary 7) were drawn (correlation co-efficient 0.999). A linear increase in the absorbance was found with an increase in saxagliptin concentration at a range of $0.01-0.25 \mu \mathrm{g} / \mathrm{mL}$ and $1-10 \mu \mathrm{g} / \mathrm{mL}$ of saxagliptin by method-1 and 2, respectively. Overlaid UVvisible spectra of saxagliptin in the linearity range is shown in Figure 6. Precision studies evinced the reproducibility of proposed method (Supplementary 8), where no significant difference between intra and inter-day precision values was observed and \% RSD values were less than 2 . The \% recoveries of saxagliptin (Supplementary 9) denote the fair accuracy of proposed methods with no interference of tablet excipients. A high value of the molar absorptivity and low values of Sandell's sensitivity, LOD, and $L O Q$ signposts the good sensitivity of proposed methods.

\section{Assay of saxagliptin marketed dosage form}

The proposed methods were applied for the assay of marketed dosage forms containing saxagliptin (label claim $5 \mathrm{mg}$ ). The

\section{Table 3. Optimized characteristics of saxagliptin}

\begin{tabular}{|c|c|c|}
\hline \multirow{2}{*}{ Parameters } & \multicolumn{2}{|c|}{ Value } \\
\hline & Method-1 & Method-2 \\
\hline $\begin{array}{l}\text { Absorption wavelength } \\
\text { (nm) }\end{array}$ & 600 & 585 \\
\hline Beers law range $(\mu \mathrm{g} / \mathrm{mL})$ & $0.01-0.25 \mu \mathrm{g} / \mathrm{mL}$ & $1-10 \mu \mathrm{g} / \mathrm{mL}$ \\
\hline Regression equation & $Y=2.7709 x+0.307$ & $Y=0.0704 x+0.2494$ \\
\hline $\begin{array}{l}\text { Correlation coefficient } \\
\left(r^{2}\right)\end{array}$ & 0.999 & 0.999 \\
\hline $\begin{array}{l}\text { Limit of detection } \\
(\mu \mathrm{g} / \mathrm{mL})\end{array}$ & 0.002 & 0.328 \\
\hline $\begin{array}{l}\text { Limit of quantification } \\
(\mu \mathrm{g} / \mathrm{mL})\end{array}$ & 0.007 & 0.994 \\
\hline $\begin{array}{l}\text { Molar absorptivity } \\
\left(\mathrm{L}_{\mathrm{mole}}^{-1} \mathrm{~cm}^{-1}\right)\end{array}$ & $0.189 \times 10^{7}$ & $0.302 \times 10^{5}$ \\
\hline $\begin{array}{l}\text { Sandell's sensitivity } \\
\left(\mu \mathrm{g} \mathrm{cm}^{-2}\right)\end{array}$ & $1.66 \times 10^{-3}$ & $1.04 \times 10^{-7}$ \\
\hline $\begin{array}{l}\text { Stability of colored } \\
\text { species }\end{array}$ & $7 \mathrm{hr}$ & $5 \mathrm{hr}$ \\
\hline
\end{tabular}
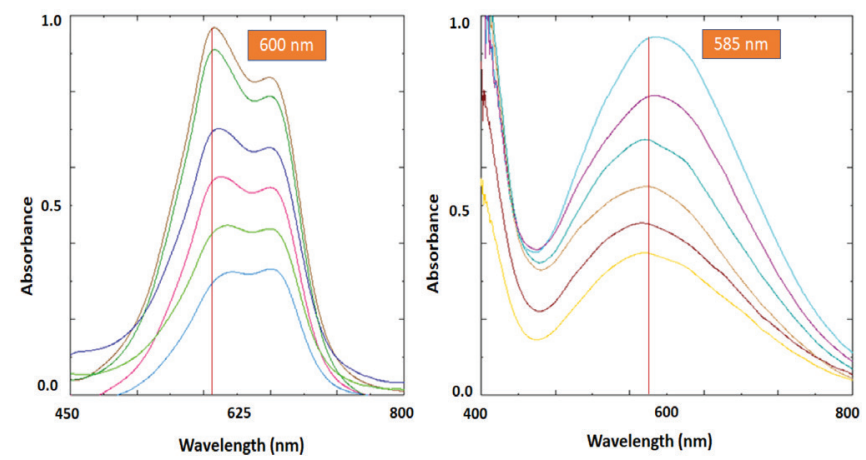

Figure 6. Overlaid UV-visible spectra (a): Saxagliptin $(0.01-0.25 \mu \mathrm{g} / \mathrm{mL}$ ) with MBTH, (b): Saxagliptin $(0.1-10 \mu \mathrm{g} / \mathrm{mL})$ with ninhydrin

UV: Ultraviole, MBTH: 3-methyl-2-benzothiazolinone hydrazone 
Table 4. Comparison of proposed method with literature methods of saxagliptin

\begin{tabular}{|c|c|c|c|c|c|c|}
\hline Parameter & Reported & od $^{21}$ & Report & ethod ${ }^{20}$ & Proposed & hod \\
\hline Chromogenic reagent & $\mathrm{DDQ}$ & TCNQ & NQS & NBD-Cl & MBTH & Ninhydrin \\
\hline$\lambda_{\max }(\mathrm{nm})$ & 461 & 838 & 475 & 470 & 600 & 585 \\
\hline $\mathrm{LOQ}(\mu \mathrm{g} / \mathrm{mL})$ & 7.68 & 8.46 & 3.01 & 1.68 & 0.007 & 0.994 \\
\hline Linearity range & $50-300$ & $10-110$ & $5-30$ & $3-20$ & $0.01-0.25$ & $1-10$ \\
\hline Reaction stability & $50 \mathrm{~min}$ & $1 \mathrm{hr}$ & $4 \mathrm{hr}$ & $4 \mathrm{hr}$ & $7 \mathrm{hr}$ & $5 \mathrm{hr}$ \\
\hline Diluting solvent & Methanol & Methanol & Water & Methanol & Water & Water \\
\hline
\end{tabular}

DDQ: (2,3-dichloro-5,6-dicyano-1,4-benzoquinone), TCNQ: (7,7,8,8-tetracyanoquinodimethane), NQS: (1,2-Naphthoquinone-4-sulfonic acid), NBD-Cl: (4-chloro-7nitrobenzofurazan), MBTH: (3-methyl-2-benzothiazolinone hydrazone), LOD: Limit of detection, LOQ: Limit of quantification, max: Maximum

$\%$ assay of saxagliptin was found to be 100.27 and 99.86 by method-1 and method-2, respectively. There was no interference of formulation excipients during the estimation of saxagliptin in tablets. The assay values were found to be within the limits and $\%$ RSD was less than 2 .

\section{Comparison with reported analytical methods}

The proposed $A Q b D$ method is found to be superior to literature methods due to its ability to predict interactive effects of parameters on the performance of the method. The literature methods have limitations such as less robust, less feasibility for method transfer, no variable- interaction study and required a high number of experiments.

\section{Study limitations}

These limitations were eliminated using RSM in this investigation. Two chromogenic reagents (MBTH and ninhydrin) were employed for chemical derivatization of saxagliptin, which were not reported earlier. From Table 4, this method was found to be highly sensitive than literature methods, owed to linearity at lower concentration range, $L O D$ and $L O Q$ values $(0.007$, 0.994). The proposed methods rely on the use of distilled water as a solvent, which point to an economical and eco-friendly method for drug analysis.

\section{CONCLUSION}

In this study, two spectrophotometric methods were developed which evaded the use of organic solvents for the analysis of saxagliptin in bulk and pharmaceutical dosage forms. Chemical derivatization mechanisms for saxagliptin with MBTH and ninhydrin were proposed. The optimization of reaction conditions for visible spectroscopic estimation of the drug was performed through $A Q b D$ approach, where experimental design (BBD, CCD), statistical analysis and response surface analysis were employed. The proposed methods obeyed validation criterion of $\mathrm{ICH}$. The assay values agreed well with the label claim and suggested that no interference of formulation excipients during the estimation of the drug. Contemplated methods are more sensitive, less chemical hazardous and versatile over reported methods. Hence, the proposed eco-friendly and economical methods can be routinely employed in quality control for the analysis of saxagliptin in the pharmaceutical dosage forms.

Conflict of interest: No conflict of interest was declared by the authors. The authors are solely responsible for the content and writing of this paper.

\section{REFERENCES}

1. Rosenstock J, Sankoh S, List JF. Glucose-lowering activity of the dipeptidyl peptidase- 4 inhibitor saxagliptin in drug-naive patients with type 2 diabetes. Diabetes Obes Metab. 2008;10:376-386.

2. Jadzinsky M, Pfützner A, Paz-Pacheco E, Xu Z, Allen E, Chen R; CV181039 Investigators. Saxagliptin given in combination with metformin as initial therapy improves glycaemic control in patients with type 2 diabetes compared with either monotherapy: a randomized controlled trial. Diabetes Obes Metab. 2009;11:611-622.

3. Rosenstock J, Aguilar-Salinas C, Klein E, Nepal S, List J, Chen R; CV181-011 Study Investigators. Effect of saxagliptin monotherapy in treatment-naïve patients with type 2 diabetes. Curr Med Res Opin. 2009;25:2401-2411.

4. Koli SN, Belvotagi AV, Mudke RP, Patil SA. UV spectrophotometric method development and validation for estimation of saxagliptin in API and in pharmaceutical dosage form. Int $\mathrm{J}$ Pharm Pharm Res. 2019;14:166-179.

5. Zameeruddin M, Bundel SS, Bharkad VB, Khan HN, Sandip TT. Development and validation of UV spectroscopic method for simultaneous estimation of dapagliflozin and saxagliptin in synthetic mixture. Int J Pharm Anal Res. 2019;8:59-66.

6. Bhadauria RS, Agarwal V. Development and validation of UV spectroscopic method for simultaneous estimation of dapagliflozin and saxagliptin in marketed formulation. J Drug Deliv Ther. 2019;9:11601164.

7. Raveendra BG, Kumar RA, Shaheen SD, Greeshma A, Satyanarayana M, Manikanta RSHT, Syam CPB. A novel stability-indicating method for the simultaneous estimation of saxagliptin and dapagliflozin in rat serum by using UV spectroscopy. Pharm Anal Acta. 2018;9:3.

8. Suthar AS, Prajapati L, Joshi A, Patel J, Kharofiya ML, Sahah SBM. Estimation of saxagliptin hydrochloride and dapagliflozin propendiol monohydrate in combined dosage form. J Innov Appl Pharm Sci. 2018;3:1-7. 
9. Sisode PS, Raj HA, Jain VC. Simultaneous determination of saxagliptin hydrochloride and glibenclamide in synthetic mixture using spectrophotometric technique (first order derivative method). Asian J Pharm Anal. 2016;6:77-82.

10. Nyola N, Jeyebalan G. Development and validation of UV-Vis spectroscopy method for simultaneous estimation of saxagliptin hydrochloride and metformin hydrochloride in active pharmaceutical ingredient. J Pharm Edu Res. 2012;3:19-23.

11. Kalaichelvi R, Jayachandran E. Validated spectroscopic method for estimation of saxagliptin in pure and from tablet formulation. Int $J$ Pharm Pharm Sci. 2011;3:179-180.

12. Veeresham C, Srividya S, Swetha E. Development and validation of high-performance thin layer chromatographic method for quantitative analysis of saxagliptin. Am J Analyt Chem. 2015;6:797-806.

13. Donepudi S, Achanta S. Simultaneous estimation of saxagliptin and dapagliflozin in human plasma by validated high performance liquid chromatography - ultraviolet method. Turk J Pharm Sci. 2019;16:227233.

14. Aswini R, Eswarudu MM, Babu PS. A novel RP-HPLC method for simultaneous estimation of dapagliflozin and saxagliptin in bulk and pharmaceutical dosage form. Int J Pharm Sci Res. 2018;9:5161-5167.

15. Adegoke OA, Babalola CP, Kotila OA, Obuebhor O. Simultaneous spectrophotometric determination of trimethoprim and sulphamethoxazole following charge-transfer complexation with chloranilic acid. Arab J Chem. 2017;10:S3848-S3860.

16. Sunil Kumar AVVNK. Reddy TV, Sekharan CB. Utility of picric acid and 2,4 dinitrophenol as chromogenic reagents for visible spectrophotometric quantification of alogliptin. Bull Fac Pharm Cairo Univ. 2017;55:177-184.

17. Pani Kumar AD, Archana G, Sunitha G, Rachel Paul K, Harika R, Sowndarya NSKR. Simplistic application of 3-methy-2-benzothiazoline hydrazone (MBTH), an oxidative coupling chromogenic reagent for quantification of metaxalone and dabigatran etexilate mesylate bulk drug and their dosage forms. Pharm Anal Acta. 2015;6:5.

18. Varsha MS, Babu NR, Padmavathi Y, Kumar PR. Development of new spectrophotometric method for estimation of tenofovir disoproxil fumarate using MBTH reagent. Int Curr Pharm J. 2015;4:378-381.

Supplementary 1. TLC analysis of saxagliptin and reaction products

\begin{tabular}{lll}
\multirow{2}{*}{ Sample } & Method-1 & Method-2 \\
\cline { 2 - 3 } & $\mathrm{R}_{\mathrm{f}}$ value & $\mathrm{R}_{\mathrm{f}}$ value \\
\hline Saxagliptin standard & $0.11 \pm 0.004$ & $0.12 \pm 0.003$ \\
\hline Reagent blank & $0.34 \pm 0.02$ & $0.46 \pm 0.03$ \\
\hline Saxagliptin-chemical derivative & $0.59 \pm 0.02$ & $0.72 \pm 0.04$ \\
\hline
\end{tabular}

TLC: Thin layer chromatography
19. Ismail NBS, Narayana B. Spectrophotometric determination and spectroscopic studies on Schiff base and charge transfer complex of ketorolac tromethamine. J Anal Sci Technol. 2015;6:32.

20. Moneeb MS. Spectrophotometric and spectrofluorimetric methods for the determination of saxagliptin and vildagliptin in bulk and pharmaceutical preparations. Bull Fac Pharm Cairo Univ. 2013;51:139-150.

21. El-Bagary RI, Elkady EF, Ayoub BM. Spectrophotometric methods based on charge transfer complexation reactions for the determination of saxagliptin in bulk and pharmaceutical preparation. Int J Biomed Sci. 2012;8:204-208.

22. Abd-alaah HJ, Hamody AS. Design of experiments model for optimization of spectrophotometric determination of phenylephrine hydrochloride in pure and pharmaceutical formulations using p-bromanil. J Pharm Sci Res. 2019:11:501-507.

23. Wani YB, Patil DD. An experimental design approach for optimization of spectrophotometric method for estimation of cefixime trihydrate using ninhydrin as derivatizing reagent in bulk and pharmaceutical formulation. J Saudi Chem Soc. 2017;21:S101-S111.

24. Papanna RK, Gowda JBK, Nagaraja P. An experimental design approach for optimization of spectrophotometric estimation of mirabegron in bulk and pharmaceutical formulations. J Anal Chem. 2018;73:884-893.

25. Demirkaya-Miloglu F, Polatdemir E, Senol O, Kadioglu Y. Design and optimization of a novel spectrophotometric method using response surface methodology for the determination of losartan potassium in pharmaceuticals. Curr Pharm Anal. 2017;13:552-558.

26. International conference on harmonization $(\mathrm{ICH})$ of technical requirements for registration of pharmaceuticals for human use, Validation of analytical procedures: Text Q2 (R1) Geneva, 2005:1-5.

27. International conference on harmonization (ICH) of technical requirements for registration of pharmaceuticals for human use, Validation of analytical procedures: Methodology. Q2 (R1) Geneva, 2005:6-13

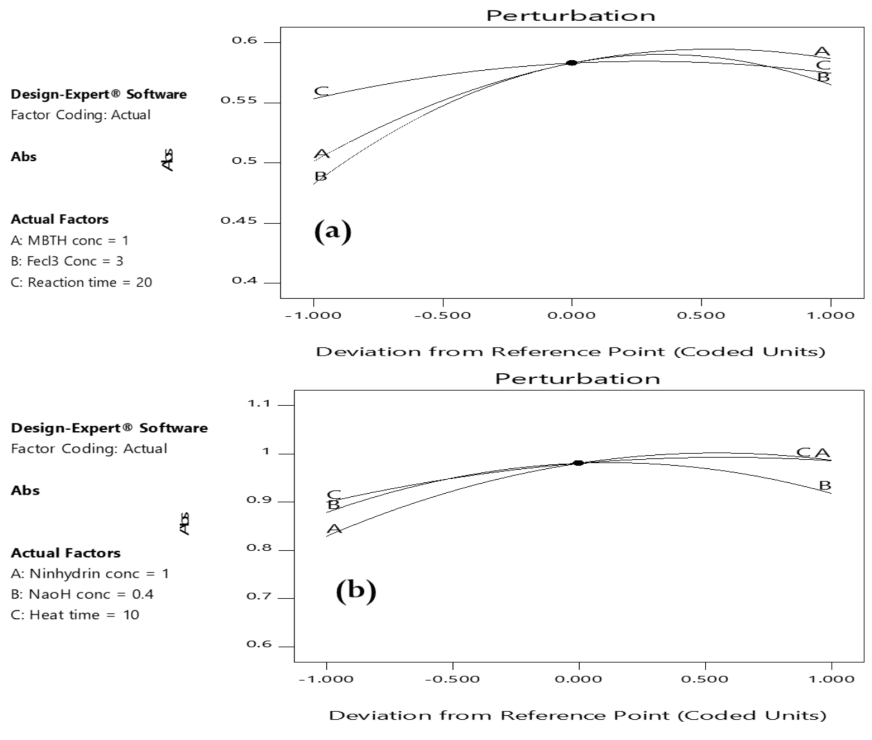

Supplementary 2. Perturbation plots of variables (a) method-1 (b) method-2 

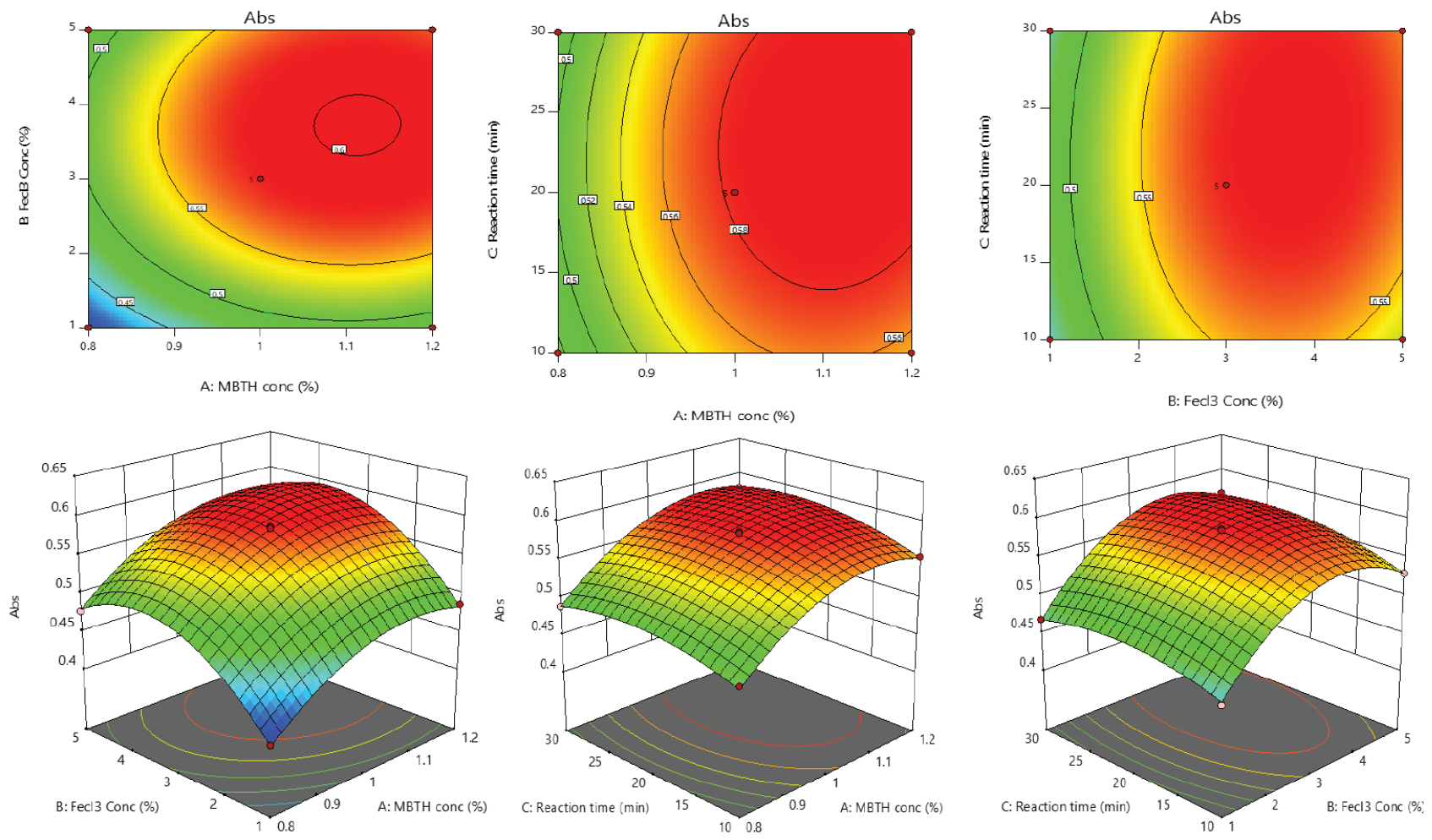

Supplementary 3. Contour (2D), response surface plots (3D) of two variable interactions in method-1
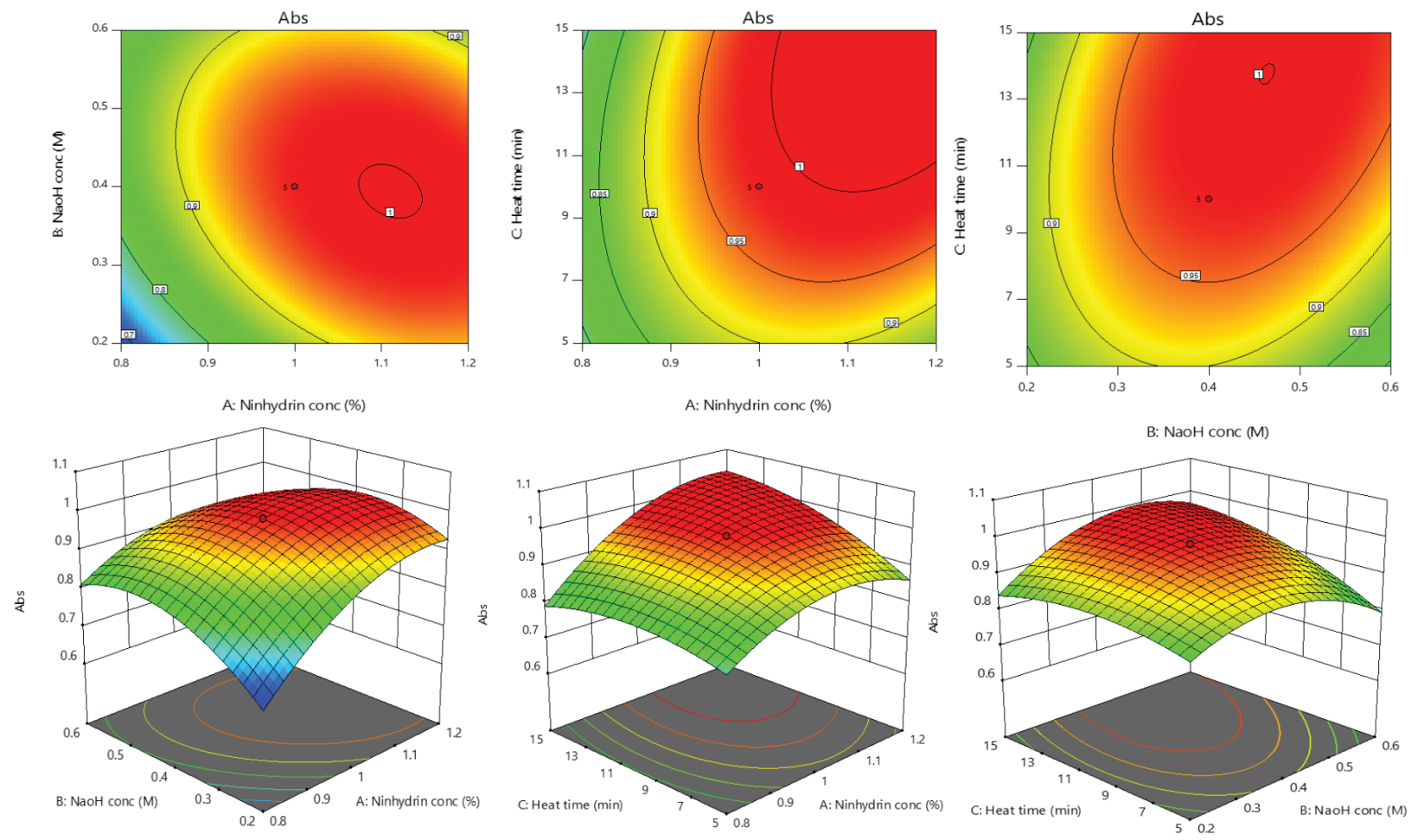

Supplementary 4. Contour (2D), response surface plots (3D) of two variable interactions in method-2 

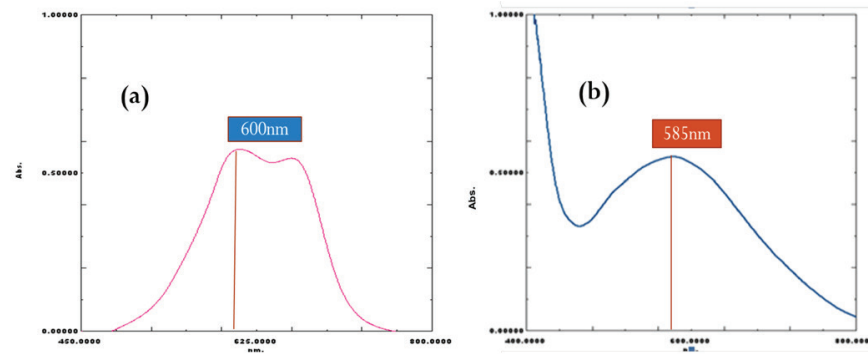

Supplementary 5. UV-visible spectrum, (a): Saxagliptin $(0.1 \mu \mathrm{g} / \mathrm{mL})$ with MBTH, (b): Saxagliptin $(5 \mu \mathrm{g} / \mathrm{mL})$ with ninhydrin

UV: Ultraviole, MBTH: 3-methyl-2-benzothiazolinone hydrazone

\section{Supplementary 6. Data of linearity studies}

\begin{tabular}{lllll} 
& Method-1 & \multicolumn{3}{c}{ Method-2 } \\
\cline { 2 - 5 } $\begin{array}{c}\text { ○ } \\
\dot{5}\end{array}$ & $\begin{array}{l}\text { Concentration } \\
(\mu \mathrm{g} / \mathrm{mL})\end{array}$ & $\begin{array}{l}\text { Absorbance } \\
(\mathrm{AM} \pm \mathrm{SD}) \\
\mathrm{n}=6\end{array}$ & $\begin{array}{l}\text { Concentration } \\
(\mu \mathrm{g} / \mathrm{mL})\end{array}$ & $\begin{array}{l}\text { Absorbance } \\
(\mathrm{AM} \pm \mathrm{SD}) \\
\mathrm{n}=6\end{array}$ \\
\hline 1 & 0.01 & $0.331 \pm 0.002$ & 1 & $0.315 \pm 0.007$ \\
\hline 2 & 0.05 & $0.445 \pm 0.007$ & 2 & $0.402 \pm 0.011$ \\
\hline 3 & 0.1 & $0.587 \pm 0.011$ & 4 & $0.525 \pm 0.015$ \\
\hline 4 & 0.15 & $0.722 \pm 0.014$ & 6 & $0.669 \pm 0.018$ \\
\hline 5 & 0.2 & $0.874 \pm 0.015$ & 8 & $0.811 \pm 0.017$ \\
\hline 6 & 0.25 & $0.989 \pm 0.015$ & 10 & $0.957 \pm 0.019$ \\
\hline
\end{tabular}
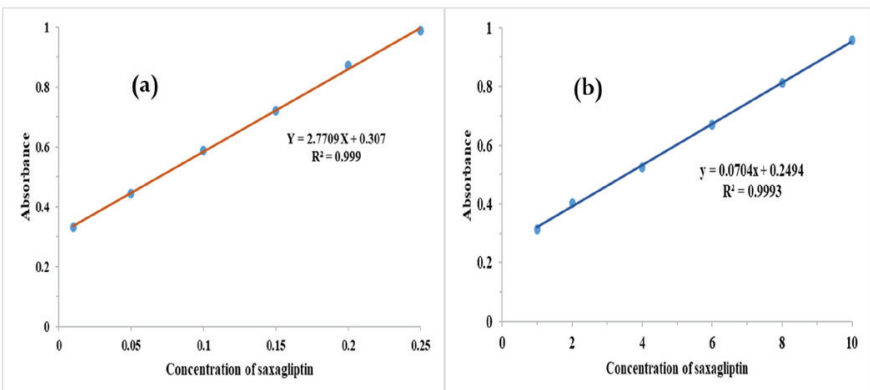

Supplementary 7. Calibration plot of saxagliptin with MBTH (a) and ninhydrin (b)

AM: Arithmetic mean, SD: Standard deviation, n: Number of determinations

MBTH: 3-methyl-2-benzothiazolinone hydrazone

Supplementary 8 . Results of precision studies

\begin{tabular}{|c|c|c|c|c|c|}
\hline \multirow[b]{2}{*}{ Method } & \multirow{2}{*}{$\begin{array}{l}\text { Concentration } \\
\text { saxagliptin }(\mu \mathrm{g} / \mathrm{mL})\end{array}$} & \multicolumn{2}{|c|}{ Intra-day analysis } & \multicolumn{2}{|c|}{ Inter-day analysis } \\
\hline & & $\begin{array}{l}\text { Concentration found } \\
(A M \pm S D), n=3\end{array}$ & $\%$ RSD & $\begin{array}{l}\text { Concentration found } \\
(A M \pm S D), n=3\end{array}$ & $\%$ RSD \\
\hline \multirow{3}{*}{ Method-1 } & 0.1 & $0.098 \pm 0.001$ & 1.02 & $0.109 \pm 0.002$ & 1.8 \\
\hline & 0.15 & $0.153 \pm 0.002$ & 1.30 & $0.159 \pm 0.003$ & 1.88 \\
\hline & 0.2 & $0.206 \pm 0.002$ & 0.97 & $0.212 \pm 0.003$ & 1.46 \\
\hline \multirow{3}{*}{ Method-2 } & 2 & $2.06 \pm 0.011$ & 0.53 & $2.08 \pm 0.021$ & 1.0 \\
\hline & 6 & $5.95 \pm 0.028$ & 0.47 & $6.01 \pm 0.032$ & 0.53 \\
\hline & 10 & $9.97 \pm 0.033$ & 0.33 & $9.95 \pm 0.024$ & 0.24 \\
\hline
\end{tabular}

AM: Arithmetic mean, SD: Standard deviation, n: Number of determinations, RSD: Relative standard deviation

\section{Supplementary 9. Results of accuracy studies of proposed methods with tablets}

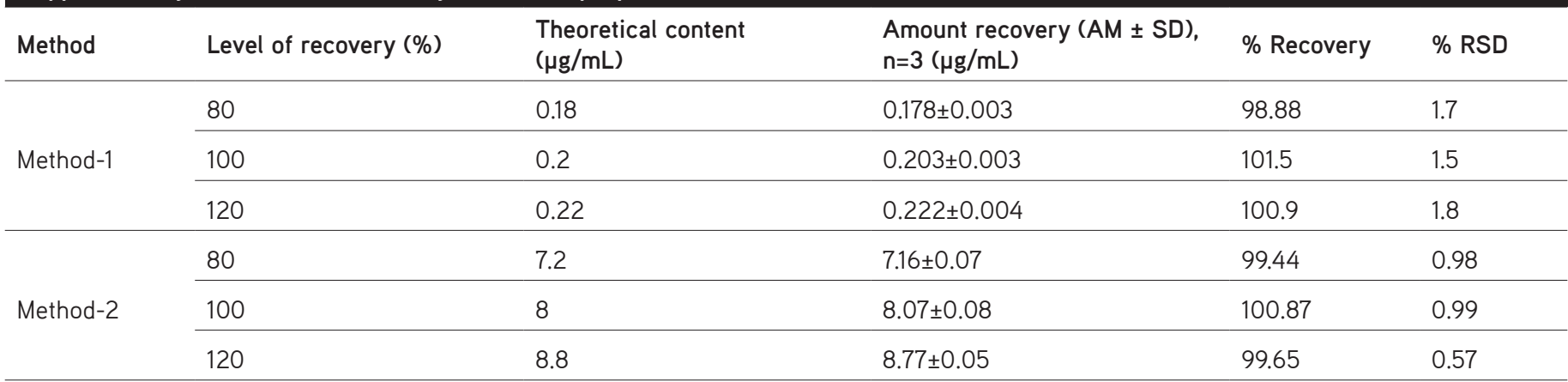

AM: Arithmetic mean, SD: Standard deviation, n: Number of determinations, RSD: Relative standard deviation 